\title{
Comparing the adsorption and desorption characteristics of $17 \alpha$-ethinylestradiol on sludge derived from different treatment units
}

\author{
Z. H. Zhang $\cdot$ Y. J. Feng $\cdot$ P. Gao $\cdot$ J. F. Liu $\cdot$ \\ N. Q. Ren
}

Received: 29 October 2010/Revised: 3 October 2011 / Accepted: 23 November 2011/Published online: 16 March 2012

(c) CEERS, IAU 2012

\begin{abstract}
The adsorption and desorption behaviors of $17 \alpha$-ethinylestradiol on various sludges derived from different treatment units of a sewage treatment plant were investigated using batch equilibration experiments. The results showed that adsorption process could be well described by pseudo-second-order kinetic model and fast adsorption played a main role. Adsorption ability varied as the order of aerobic sludge $\approx$ anoxic sludge $\approx$ primary sludge $>$ sludge cake $>$ anaerobic sludge. Adsorption/ desorption isotherms were well fitted by the modified Freundlich model, and $K_{f}^{\prime}$ values increased with the organic matter content. Thermodynamic analysis indicated that $17 \alpha$-ethinylestradiol adsorption/desorption was exothermic and conducted spontaneously. After heat treatment for removing the organic carbon, $K_{f}^{\prime}$ values decreased by more than $78 \%$, but organic carbon normalized adsorption constant was $7.76-29.51 \mathrm{mg} / \mathrm{g}$. The $17 \alpha$-ethinylestradiol adsorption capacity was found to decrease from $0.95-1.39$ to $0.44-0.49 \mathrm{mg} / \mathrm{g}$ with sludge concentration increasing from 500 to $4,000 \mathrm{mg} / \mathrm{L}$, being almost unchanged at $\mathrm{pH}$ $3-10$ and sharply decreasing with $\mathrm{pH}>10$. The adsorption capacity was also found to fluctuate in the range of $2.0-3.0 \mathrm{mg} / \mathrm{g}$ when $\mathrm{Ca}^{2+}$ concentration was $<0.5 \mathrm{~mol} / \mathrm{L}$ and increased rapidly above $0.5 \mathrm{~mol} / \mathrm{L}$. Addition of methanol and acetonitrile could improve $17 \alpha$-ethinylestradiol desorption effect, which increased with the content of organic solvents, and the desorption degree of acetonitrile was higher than methanol.
\end{abstract}

Z. H. Zhang · Y. J. Feng $(\bowtie) \cdot$ P. Gao · J. F. Liu $\cdot$ N. Q. Ren State Key Laboratory of Urban Water Resource and Environment, Harbin Institute of Technology, No73, Huanghe Road, Nangang District, Harbin 150090, China e-mail: yujief@hit.edu.cn
Keywords Adsorption behavior - Desorption hysteresis . Organic carbon $\cdot$ Synthetic estrogen · Various sludges

\section{Introduction}

$17 \alpha$-Ethinylestradiol $\left(\mathrm{EE}_{2}\right)$, which is a synthetic estrogen used primarily in contraceptive pills and hormone replacement therapy, is released into the water environment through two ways: one is in domestic sewage excreted by humans and mammals mainly through their urine in the form of conjugated glucuronide or sulfate complexes (Tyler et al. 1998; Panter et al. 1999); the other is in industrial wastewater mainly from some pharmaceutical companies (Cui et al. 2006). $\mathrm{EE}_{2}$ has an extensive distribution in aquatic environments (Chang et al. 2003; Cargouet et al. 2004). Previous surveys indicated that $\mathrm{EE}_{2}$ was normally present in the lower $\mathrm{ng} / \mathrm{L}$ in wastewater treatment plant (WWTP) effluents, ranging from 0.5 to $10 \mathrm{ng} / \mathrm{L}$ (Ternes et al. 1999). However, the $\mathrm{EE}_{2}$ maximum levels in domestic wastewater was $7 \mathrm{ng} / \mathrm{L}$ (Cargouet et al. 2004; Ifelebuegu 2011), which meant that $\mathrm{EE}_{2}$ could be separated from conjugated glucuronide or sulfate complexes by the function of microorganisms (Panter et al. 1999). In addition, $\mathrm{EE}_{2}$ concentration in river water ranged from below the detection limit to $4.09 \mathrm{ng} / \mathrm{L}$ with a maximum concentration of $48.8 \mathrm{ng} / \mathrm{L}$ (Chang et al. 2003; Zhang et al. 2011).

Although $\mathrm{EE}_{2}$ concentration is low (at $\mathrm{ng} / \mathrm{L}$ level), it is considered to be the main contributor to estrogenicity in environmental samples and causes a wide variety of effects on the ecological system (Thomas et al. 2001; Johnson and Williams 2004). It can misregulate or interfere with normal biological responses by binding to the estrogen receptor and stimulating the growth of human breast cancer cells (Soto et al. 1991) or inducing the expression of vitellogenin in fish 
(Kwak et al. 2001). It was reported that a $0.1 \mathrm{ng} / \mathrm{L}$ level of $\mathrm{EE}_{2}$ was able to induce the expression of vitellogenin in fish, 0.1-15 ng/L could affect the sex differentiation, and long exposure to $5 \mathrm{ng} / \mathrm{L}$ might lead to significant reduction in fish fecundity (Nash et al. 2004; Fent et al. 2006).

In sewage treatment plants (STPs), estrogen compounds can be removed by three major mechanisms such as volatilization, biodegradation and adsorption (Khanal et al. 2006). However, for $\mathrm{EE}_{2}$, its low vapor pressure $\left(3 \times 10^{-7} \mathrm{~Pa}\right)$ determines its poor volatilization during the treatment process (Feng et al. 2010), while its structure also determines its difficulty to be biodegraded in normal biological treatment processes (Kanda and Churchley 2008). The relatively high octanol-water partition coefficient $\left(\log K_{\mathrm{OW}}=3.6-3.8\right)$ of $\mathrm{EE}_{2}$ also makes it very easy to adsorb to the sludge (Feng et al. 2010; Ifelebuegu et al. 2010). Therefore, adsorption is the only main removal mechanism of $\mathrm{EE}_{2}$ in STPs. Previous studies also confirmed that $\mathrm{EE}_{2}$ was strongly adsorbed onto the activated sludge particles in municipal wastewater treatment plants (Andersen et al. 2005; Cirja et al. 2007). Ren et al. (2007) investigated the thermodynamics of $\mathrm{EE}_{2}$ adsorption onto activated sludge biomass and determined that $\mathrm{EE}_{2}$ adsorption was an exothermic process. Clara et al. (2004) found that the $\mathrm{EE}_{2}$ adsorption behaviors on both activated and inactivated sludge were affected by $\mathrm{pH}$ value. $\mathrm{Xu}$ et al. (2008) compared the adsorption characteristics of $\mathrm{EE}_{2}$ on the membrane bioreactor (MBR) and sequencing batch reactor (SBR) sludge and determined the thermodynamic parameters and adsorption mechanism. However, no information about the adsorption and desorption characteristics of $\mathrm{EE}_{2}$ on the different sources of sludge from an STP has been found in previous studies.

The overall objective of the present study was to compare the adsorption and desorption characteristics of $\mathrm{EE}_{2}$ on various sludges derived from different treatment units. The adsorption and desorption kinetics and isotherms of $\mathrm{EE}_{2}$ on various sludges were obtained. In addition, how the operational parameters, including sludge concentration, $\mathrm{pH}$ value and ionic strength, affect the adsorption process and how the co-solvent influences the desorption process were also evaluated. The results of this study provide a better understanding of environmental behaviors of $\mathrm{EE}_{2}$ in STPs and contribute to risk assessment and fate modeling of $\mathrm{EE}_{2}$ in urban water.

The experiments for this study were conducted from September to December 2009, and at the Laboratory of Harbin Institute of Technology, located in Harbin, Heilongjiang Province, China.

\section{Materials and methods}

Reagents and chemicals

The compound $\mathrm{EE}_{2}$ purchased from Sigma, China was chromatographically pure $(>99 \%)$. The chemical structure and physico-chemical properties have been described in a previous study (Feng et al. 2010) and the detailed information is also listed in Table $1 . \mathrm{EE}_{2}$ has relatively high logarithmic value of octanol-water partitioning coefficient (3.6-3.8), and relatively low solubility in water $(4.8 \mathrm{mg} / \mathrm{L}$ at $25^{\circ} \mathrm{C}$ ). Co-solvent, such as methanol or acetone, was not used to avoid the influence on $\mathrm{EE}_{2}$ adsorption. The $\mathrm{EE}_{2}$ solution was prepared by dissolving $\mathrm{EE}_{2}$ solid in deionized water for 2 days and filtering the solid with $0.45 \mu \mathrm{m}$ polytetrafluoroethylene (PTFE) membranes before use. The actual $\mathrm{EE}_{2}$ concentration was determined by HPLC. All other chemicals and solvents (such as methanol, acetonitrile, $\mathrm{HCl}, \mathrm{NaOH}$ and $\mathrm{CaCl}_{2}$ ) were of analytical reagent grade or better. High-purity water was produced using a MilliQ Plus system (Millipore, USA).

\section{Sorbents-sludge}

The sludge was taken from Taiping wastewater treatment plant which operated at an anoxic/aerobic mode and mainly treated civil domestic wastewater from the Harbin urban area. Five kinds of sludge, primary sludge (PS), anaerobic sludge (AnaS), anoxic sludge (AnoS), aerobic sludge (AS) and sludge cake (CS), were sampled and stored in glass containers and then transported to the laboratory in $2 \mathrm{~h}$. The sludge was first washed with fresh water for three to four times and centrifuged at 4,000 rpm for $20 \mathrm{~min}$ to

Table 1 Physiochemical properties of $\mathrm{EE}_{2}$

\begin{tabular}{lllll}
\hline Estrogen & Formula & CAS number & $\lambda_{\text {max }}$ & Water solubility \\
\hline $\mathrm{EE}_{2}$ & $\mathrm{C}_{20} \mathrm{H}_{24} \mathrm{O}_{2}$ & $57-63-6$ & $278 \mathrm{~nm}$ & $4.8 \mathrm{mg} / \mathrm{L}$ \\
$\mathrm{MW}$ & $\log K_{\mathrm{OW}}$ & Melting point & Chemical structure \\
296.4 & $3.6-3.8$ & $182-184^{\circ} \mathrm{C}$ & 10.5
\end{tabular}


remove water-soluble constituents and then freeze dried, followed by homogenization and sieving with a 100-mesh screen.

The organic carbon content of the sludge samples was determined using a TOC analyzer (Shimadzu, SSM$5000 \mathrm{~A}$ ). In addition to the raw sludge samples, a portion of each sludge sample was combusted for $24 \mathrm{~h}$ at 375 and $600^{\circ} \mathrm{C}$ under air in a muffle furnace. The remaining organic carbon content on $375^{\circ} \mathrm{C}$ heat-treated sludge was termed as black carbon, while $600^{\circ} \mathrm{C}$ heat-treated sludge contained almost no organic carbon $(\mathrm{OC}<0.3 \%) . \mathrm{EE}_{2}$ adsorption and desorption experiments were conducted on both the raw and $375^{\circ} \mathrm{C}$ heat-treated sludge.

\section{Adsorption/desorption experiments}

\section{Adsorption/desorption kinetic study}

For the adsorption kinetic test, $0.1 \mathrm{~g}$ of dry sludge was added to each of five $250-\mathrm{mL}$ conical flasks containing $200 \mathrm{~mL}$ of solution having $2.32 \mathrm{mg} / \mathrm{L}$ of $\mathrm{EE}_{2}$. Sodium azide of $0.02 \%$ was added $(\mathrm{w} / \mathrm{w})$ to inhibit bacterial growth (Xu et al. 2008). The sludge mixture was kept in an orbital shaker and rotated at $150 \mathrm{rpm}$ for $45 \mathrm{~h}$ at room temperature of $25^{\circ} \mathrm{C} ; 1 \mathrm{~mL}$ of the sample was collected from the flasks at the predetermined time intervals of $0.08,0.17,0.33$, $0.67,1,2,4,8,21$ and $45 \mathrm{~h}$. The collected samples were filtered with $0.45 \mu \mathrm{m}$ PTFE membranes and analyzed by HPLC. For desorption kinetics of $\mathrm{EE}_{2}$ on various sludges, when the system (containing $0.2 \mathrm{~g}$ various sludge) reached adsorption equilibrium, it was centrifuged for $20 \mathrm{~min}$ at 4,000 rpm and the supernatant liquid was decanted. Then, $200 \mathrm{~mL}$ of distilled water including $\mathrm{NaN}_{3}$ was added for the study of the desorption process of $\mathrm{EE}_{2}$ on sludge at $150 \mathrm{rpm}$ and $25^{\circ} \mathrm{C} ; 1 \mathrm{~mL}$ of samples were taken at the time intervals of $0.25,0.5,0.75,1,2,4,6,8,20$ and $32 \mathrm{~h}$, and treated as above to analyze $\mathrm{EE}_{2}$ in the aqueous phase.

\section{Adsorption/desorption equilibrium studies}

Adsorption/desorption equilibrium studies were conducted for all raw and heat-treated sludge in $100-\mathrm{mL}$ conical flasks, containing $40 \mathrm{~mL}$ of liquor with different $\mathrm{EE}_{2}$ content and $40 \mathrm{mg}$ of sludge. Initial $\mathrm{EE}_{2}$ concentrations of $2.80,2.52,2.24,1.68,1.40,1.12,0.56$ and $0.28 \mathrm{mg} / \mathrm{L}$ were set. The flasks were sealed with rubber plug and shaken on the rotary shaker $(125 \mathrm{rpm})$ at $25^{\circ} \mathrm{C}$ in the dark. After reaching adsorption equilibrium, $1-\mathrm{mL}$ samples were collected and treated as above. A control experiment without sludge was also simultaneously conducted. It was found that the total loss of $\mathrm{EE}_{2}$ from photochemical degradation, volatilization and adsorption to the bottle glass was less than $5 \%$ of the $\mathrm{EE}_{2}$ added.
For desorption equilibrium studies, when the system reached adsorption equilibrium, the mixtures were centrifuged for $20 \mathrm{~min}$ at $4,000 \mathrm{rpm}$. Then, $25 \mathrm{~mL}$ of supernatants was withdrawn from the flask and compensated with the same volume of fresh blank liquor. The flasks were placed on the shaker for $24 \mathrm{~h}$ at $25^{\circ} \mathrm{C}$ to re-equilibrate the system. Finally, the collected samples were treated and analyzed as described above.

\section{Effect of sludge concentration on $E E_{2}$ adsorption}

The sludge concentration was adjusted to $500,1,000$, $1,500,2,000,2,500,3,000$ and $4,000 \mathrm{mg} / \mathrm{L}$ by adding different masses of the five raw sludges in $40 \mathrm{~mL}$ of $\mathrm{EE}_{2}$ solution. The initial $\mathrm{EE}_{2}$ concentration was set as $2.80 \mathrm{mg} /$ L. Experimental conditions were modulated for the equilibration process including temperature $25^{\circ} \mathrm{C}$, rotating speed $150 \mathrm{rpm}$ and equilibrium duration $24 \mathrm{~h}$.

\section{Effect of $\mathrm{pH}$ and ion strength on $\mathrm{EE}_{2}$ adsorption}

The initial $\mathrm{pH}$ of the mixture solution contained $\mathrm{EE}_{2}$ and sludge mixtures were adjusted to $3.1,6.9,10.1,10.5,11.0$, 11.5 and 12.0 with $0.5 \mathrm{~mol} / \mathrm{L} \mathrm{HCl}$ or $\mathrm{NaOH}$ to study the effect of $\mathrm{pH}$ on $\mathrm{EE}_{2}$ adsorption. For the ion strength effect study, $\mathrm{CaCl}_{2}$ was chosen to adjust ion strength to $0.001,0.01$, $0.1,0.2,0.5,0.8$ and $1 \mathrm{~mol} / \mathrm{L}$. The adsorption isotherms of $\mathrm{EE}_{2}$ at different $\mathrm{pH}$ and ion strengths were obtained according to the similar procedure as described above.

\section{Effect of co-solvents on $E_{2}$ desorption}

Methanol and acetonitrile were selected as organic solvents to study the desorption process of $\mathrm{EE}_{2}$. The initial $\mathrm{EE}_{2}$ concentration was set as $2.80 \mathrm{mg} / \mathrm{L}$ and sludge concentration to $2,000 \mathrm{mg} / \mathrm{L}$. After equilibrium, the blank liquor with different ratio of organic solvent was used as desorption solution to evaluate the desorption effect. The organic solvent content $(\mathrm{v} / \mathrm{v})$ was set as $1,2.5,5,7.5,10$, $15,20,25,30$ and $50 \%$. After re-equilibrating for $24 \mathrm{~h}$, the samples were collected and treated as above.

\section{$E E_{2}$ content detection}

The $\mathrm{EE}_{2}$ concentration in the liquid phase was determined by HPLC (SPD-10A VP, SHIMADZU) equipped with an Extend- $\mathrm{C}_{18}$ reversed-phase column $(250 \times 4.6 \mathrm{~mm}$, particle size $5 \mu \mathrm{m}$ ) and a fluorescence detector (HP 1064A) (Feng et al. 2010). The mobile phase was acetonitrile/ $10 \mathrm{mM}$ phosphoric $(50: 50, \mathrm{v} / \mathrm{v})$ and the flow rate was $1.0 \mathrm{~mL} / \mathrm{min}$. The temperature of the column was $40^{\circ} \mathrm{C}$. An excitation wavelength of $229 \mathrm{~nm}$ and emission wavelength of $309 \mathrm{~nm}$ were used for fluorescence detection. 


\section{Data analysis}

The $\mathrm{EE}_{2}$ adsorbed on the sludge $\left(Q_{t}\right)$ at any time $t$ is calculated with the following mass balance equation:

$Q_{t}=\frac{\left(C_{0}-C_{t}\right) V}{M}$

where $Q_{t}$ is the $\mathrm{EE}_{2}$ adsorbed by sludge, $\mathrm{mg} / \mathrm{g} ; C_{t}$ and $C_{0}$ $(\mathrm{mg} / \mathrm{L})$ are the initial and the water-phase concentration of $\mathrm{EE}_{2}$, respectively, at any time $t ; M$, the sludge mass introduced in each flask, $g$; $V$, the volume of the water phase.

The $\mathrm{EE}_{2}$ adsorption/desorption equilibrium data were fitted by the revised Freundlich equation shown in Eq. 2 proposed by Carmo et al. (2000).

$Q_{\mathrm{e}}=K_{f}^{\prime}\left(\frac{C_{\mathrm{e}}}{S_{\mathrm{W}}}\right)^{n}$

where $Q_{\mathrm{e}}$ and $C_{\mathrm{e}}$ are the equilibrium of solid-phase and aqueous-phase $\mathrm{EE}_{2}$ concentrations (expressed as $\mathrm{mg} / \mathrm{g}$ and $\mathrm{mg} / \mathrm{L}) ; K_{f}^{\prime}$, the revised Freundlich capacity parameter; $n$, the site energy linearity factor; $S_{\mathrm{W}}$, the aqueous $\mathrm{EE}_{2}$ solubility $(\mathrm{mg} / \mathrm{L})$, is constant at any given condition.

Considering the organic matter on the sludge, the organic carbon normalized adsorption/desorption constant, $K_{\mathrm{OC}}$, could be calculated as

$K_{\mathrm{OC}}=\frac{K_{f}^{\prime}}{f_{\mathrm{OC}}}$

where $f_{\mathrm{OC}}$ is the organic carbon content of sludge $(\%)$.

The change in the distribution molar free energy in the adsorption/desorption process can be calculated from the thermodynamic relationship,

$\Delta G^{o}=-R T \ln K_{\mathrm{OC}}$

where $\Delta G^{\circ}$ is the free energy change $(\mathrm{kJ} / \mathrm{mole}) ; R$ is the gas constant $(8.314 \mathrm{~J} / \mathrm{K}$ mole $) ; T$ is the absolute temperature (K).

The hysteresis index (HI) for the adsorption-desorption isotherms was calculated with the formula (Pusino et al. 2004).

$\mathrm{HI}=\frac{n_{\mathrm{des}}}{n_{\mathrm{ads}}}$

where $n_{\text {des }}$ and $n_{\text {ads }}$ are the Freundlich exponents of the desorption and adsorption isotherms, respectively.

\section{Results and discussions}

\section{Adsorption/desorption kinetics}

Adsorption/desorption kinetics studies were carried out to determine the uptake and desorption capacity of $\mathrm{EE}_{2}$ on the
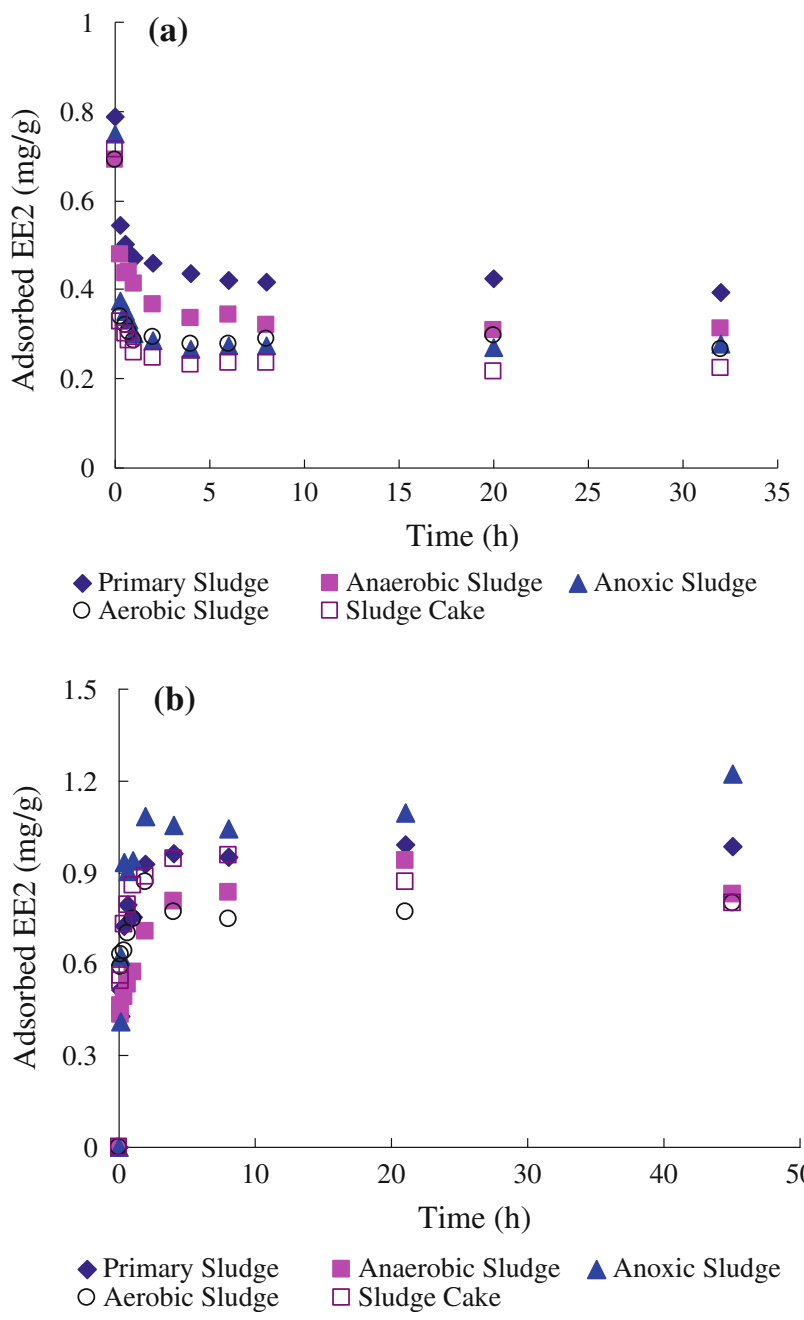

Fig. 1 Adsorption (a) and desorption (b) kinetics of $\mathrm{EE}_{2}$ on various sludges derived from different treatment units of a sewage treatment plant (initial $\mathrm{EE}_{2}$ concentration $2.34 \mathrm{mg} / \mathrm{L}$; temperature $25^{\circ} \mathrm{C}$; agitation $150 \mathrm{rpm}$; sludge concentration $500 \mathrm{mg} / \mathrm{L}$ (adsorption) and $1,000 \mathrm{mg} / \mathrm{L}$ (desorption); $\mathrm{pH} 6.9$ )

various sludges and access the equilibrium time. Figure 1a shows the variations of $\mathrm{EE}_{2}$ adsorbed onto various sludges which increased with contact time. It could be seen that the $\mathrm{EE}_{2}$ adsorption exhibited two distinct stages, a very rapid adsorption within $1 \mathrm{~h}$ followed by a slow adsorption. More than $80 \%$ of $\mathrm{EE}_{2}$ was adsorbed on various sludges in the first $1 \mathrm{~h}$. It can be inferred that the contribution of rapid adsorption was more significant as compared to slow adsorption. The rapid initial adsorption of $\mathrm{EE}_{2}$ may be explained by the hydrophobic nature of $\mathrm{EE}_{2}$, and suggested that the chemical partition domain in the sludge was more dominant than the hole-filling domain (Pignatello and Xing 1996). The adsorbed $\mathrm{EE}_{2}$ was almost unchanged after $4 \mathrm{~h}$, which indicated that adsorption equilibrium was achieved in all the sludge mixtures. The equilibrium adsorption amount of $\mathrm{EE}_{2}$ on the sludge was in the range of $0.79-1.12 \mathrm{mg} / \mathrm{g}$. 
Figure $1 \mathrm{~b}$ shows that the $\mathrm{EE}_{2}$ adsorbed amount on various sludges decreased with contact time. The desorption process also contained a quick and slow desorption. In the first $15 \mathrm{~min}$, more than $55 \%$ of the equilibrium-adsorbed $\mathrm{EE}_{2}$ was desorbed from the various sludges; the desorption reached equilibrium after $4 \mathrm{~h}$. The equilibrium-desorbed amount of $\mathrm{EE}_{2}$ from various sludges was in the range of $0.39-0.49 \mathrm{mg} / \mathrm{g}$.

The adsorption/desorption data of $\mathrm{EE}_{2}$ on five raw sludges were fitted by the pseudo-second-order kinetic model as expressed in Eq. 6,

$\frac{t}{q_{t}}=\frac{1}{k_{2} q_{\mathrm{e}}^{2}}+\left(\frac{1}{q_{\mathrm{e}}}\right) t$

where $k_{2}$ is the pseudo-second-order kinetic rate constant $\left(\mathrm{g} \mathrm{mg}^{-1} \min ^{-1}\right) ; q_{t}$, the adsorbed $\mathrm{EE}_{2}$ on sludge at time $t$ $(\mathrm{mg} / \mathrm{g}) ; q_{\mathrm{e}}$, the equilibrium-adsorbed amount of $\mathrm{EE}_{2}$ on sludge $(\mathrm{mg} / \mathrm{g})$.

The half adsorption/desorption time $\left(t_{1 / 2}\right)$ and the initial adsorption/desorption rate $(h)$ (Feng et al. 2010) were calculated with the following equations,

$t_{1 / 2}=1 / k_{2} q_{\mathrm{e}}$

$h=k_{2} q_{\mathrm{e}}^{2}$

The corresponding kinetic parameters of $\mathrm{EE}_{2}$ adsorption and desorption onto various sludges are listed in Table 2. It could be seen that the pseudo-second-order kinetics fitted the data well (all $R^{2}>0.99$ ). The adsorption rate constants were in the range of $0.0636-0.1720 \mathrm{~g} /(\mathrm{mg} . \mathrm{min})$, and the order of $k_{2}$ for various sludges were: $\mathrm{AS} \approx \mathrm{AnaS}>$ $\mathrm{PS}>\mathrm{AnoS} \approx \mathrm{CS}$. The half adsorption time $\left(t_{1 / 2}\right)$ and the initial adsorption rate $(h)$ of various sludges were in the range of $7.32-16.42 \mathrm{~min}$ and $0.058-0.113 \mathrm{mg} /(\mathrm{g} \mathrm{min})$, respectively. Moreover, the desorption rate constants were in the range of $0.144-1.545 \mathrm{~g} /(\mathrm{mg} \cdot \mathrm{min})$, and the order of $k_{2}$ for various sludges were: AnoS $>\mathrm{CS}>$ $\mathrm{AS}>\mathrm{AnaS} \approx \mathrm{PS}$. The half desorption time $\left(t_{1 / 2}\right)$ and the initial desorption rate $(h)$ of various sludges were in the range of $1.36-17.93 \mathrm{~min}$ and $0.022-0.349 \mathrm{mg} /(\mathrm{g} \mathrm{min})$.

It has been well documented that the overall adsorption rate in sludge was determined by the rate of boundary layer diffusion, intraparticle diffusion and adsorption on active sites (Leyva-Ramos et al. 2007). The boundary layer diffusion depended on several parameters, such as the solution concentration, the agitation velocity and the external surface area of the sludge, which was mainly controlled by the particle size, shape and density of the sludge. The intraparticle diffusion rate was related to the intraparticle diffusivity, the particle radius and the equilibrium $\mathrm{EE}_{2}$ concentration on the sludge. Greater particle size of sludge generally caused higher intraparticle diffusion resistance in the adsorption process (Kannan and Sundaram 2001). The adsorption rate at an active site was instantaneous. Therefore, the boundary layer and intraparticle diffusion were the rate-controlling steps, which were mainly related to the sludge characteristics. Aerobic sludge had smaller particular size and larger $\mathrm{EE}_{2}$ adsorption amount than the other sludge.

\section{Adsorption/desorption isotherms}

To compare the adsorption characteristics of $\mathrm{EE}_{2}$ on different sludges, the revised Freundlich equations, in which the modified Freundlich coefficients $\left(K_{f, A}^{\prime}\right)$ had units that were independent of the values of $n$, were used to model the $\mathrm{EE}_{2}$ adsorption. The model parameters presented in Table 2 indicate that all the adsorption isotherms of $\mathrm{EE}_{2}$ on five types of sludge are well fitted by the revised Freundlich equation. The adsorbed capacity $\left(K_{f, A}^{\prime}\right)$ of various sludges was in the range of $1.98-2.68 \mathrm{mg} / \mathrm{g}$, and the order was: $\mathrm{AS} \approx \mathrm{AnoS} \approx \mathrm{PS}>\mathrm{CS}>\mathrm{AnaS}$. Previous study showed that $K_{f}$ value of BPA adsorption increased from 0.0072 to $0.0178 \mathrm{mg}^{1-n} \mathrm{~L}^{n} \mathrm{~g}^{-1}$ with the soil organic carbon content increasing from 2.06 to $6.29 \%$ (Zeng et al.
Table 2 Pseudo-second-order kinetic parameters for the adsorption and desorption of $\mathrm{EE}_{2}$ onto sludge derived from different treatment units

\begin{tabular}{lllcll}
\hline Sludge type & $k_{2} \mathrm{~g} /(\mathrm{mg} \min )$ & $q_{\mathrm{e}}(\mathrm{mg} / \mathrm{g})$ & $t_{1 / 2}(\mathrm{~min})$ & $h \mathrm{mg} /(\mathrm{g} \min )$ & $R^{2}$ \\
\hline Adsorption & & & & & \\
Primary sludge & 0.1155 & 0.9891 & 8.7505 & 0.113 & 0.9999 \\
Anaerobic sludge & 0.1567 & 0.8355 & 7.6395 & 0.109 & 0.9999 \\
Anoxic sludge & 0.0706 & 1.1254 & 12.5951 & 0.089 & 0.9998 \\
Aerobic sludge & 0.1720 & 0.7946 & 7.3176 & 0.109 & 0.9997 \\
Sludge cake & 0.0636 & 0.9578 & 16.4151 & 0.058 & 0.999 \\
Desorption & & & & & \\
Primary sludge & 0.1435 & 0.3901 & 17.8580 & 0.022 & 0.9982 \\
Anaerobic sludge & 0.1446 & 0.3855 & 17.9325 & 0.022 & 0.9997 \\
Anoxic sludge & 1.5452 & 0.4753 & 1.3615 & 0.349 & 0.9999 \\
Aerobic sludge & 0.3100 & 0.4181 & 7.7153 & 0.054 & 0.9981 \\
Sludge cake & 0.3723 & 0.4940 & 5.4367 & 0.091 & 0.9999 \\
\hline
\end{tabular}


2006). The results of this study indicated that the $K_{f, A}^{\prime}$ value of $\mathrm{EE}_{2}$ followed a linear relationship with the organic carbon content of sludge $\left(K_{f, A}^{\prime}=0.1560 \mathrm{O}-4.607, R^{2}=\right.$ 0.913). In addition, the isotherms were almost linear for all raw sludge with slopes $(n) \approx 1$, resembling the C-type curves performed, which indicated that adsorption was mainly a partitioning mechanism between sludge organic matter and solution (Flores et al. 2009). The order of $n$ value was: $\mathrm{AS}>\mathrm{AnoS} \approx \mathrm{CS} \approx \mathrm{PS}>\mathrm{AnaS}$. The higher the $n$ value, the less heterogeneous is the adsorption site energy distribution (Ran et al. 2007).

Desorption isotherms of five raw sludges also followed revised Freundlich model $\left(r^{2}=0.975-0.993\right)$. Desorption values $\left(K_{f, D}^{\prime}\right)$ were higher than adsorption values $\left(K_{f, A}^{\prime}\right)$ for all raw sludges. The desorbed capacity $\left(K_{f, D}^{\prime}\right)$ of various sludges was in the range of $2.34-4.26 \mathrm{mg} / \mathrm{g}$, and the order was: $\mathrm{AS}>\mathrm{AnoS}>\mathrm{PS}>\mathrm{AnaS}>\mathrm{CS}$. $K_{f, D}^{\prime}$ value for $\mathrm{EE}_{2}$ also followed a linear relationship with the organic carbon content of sludge $\left(K_{f, D}^{\prime}=0.3890 C-14.422, R^{2}=0.746\right)$. The order of $n$ value was: $\mathrm{AS}>\mathrm{AnoS}>\mathrm{PS} \approx \mathrm{CS}>$ AnaS, which was all very close to one and had very similar phenomenon with the adsorption process.

\section{Adsorption-desorption hysteresis}

The HI value can be used to describe the hysteresis effect. Generally, a value of $\mathrm{HI}$ close to one indicates that desorption occurs as quickly as adsorption does, and hysteresis is absent; a value of $\mathrm{HI}<1$ means that the rate of desorption is lower than that of adsorption and hysteresis occurs (Pusino et al. 2004). From Table 3, the HI values of all raw and heat-treated sludge were in the range of 0.59 1.59, which indicated that the hysteresis degrees of $\mathrm{EE}_{2}$ on various sludges were different. The highest hysteresis effect was observed in $600^{\circ} \mathrm{C}$-treated primary sludge, which had a low adsorption capacity. The HI values of other sludges were all above 0.92 , which indicated that the hysteresis effect was insignificant and there were less chemical bonds or high-energy binding sites between $\mathrm{EE}_{2}$ molecule and sludge. Therefore, it can be predicted that $\mathrm{EE}_{2}$ will both exist in sludge and water in the case of accidental spills, and sludge should be treated in depth to avoid the release of $\mathrm{EE}_{2}$ into the environment. Moreover, the characteristics and components of sludge can significantly influence the mobility and transport of $\mathrm{EE}_{2}$ in the sewage.

Effect of organic matter on $\mathrm{EE}_{2}$ adsorption and desorption

The organic carbon of the sludge can profoundly affect the adsorption of organic pollutants. As shown in Table 4, after heat treatment, the organic carbon of various sludges decreased evidently and the adsorption isotherms of treated
Table 3 The adsorption and desorption isotherm parameters of $\mathrm{EE}_{2}$ on different sludge by modified Fruendlich models

\begin{tabular}{|c|c|c|c|c|c|c|c|}
\hline \multirow[t]{2}{*}{ Sludge type } & \multicolumn{3}{|l|}{ Adsorption } & \multicolumn{3}{|l|}{ Desorption } & \multirow[t]{2}{*}{ Hysteresis index } \\
\hline & $K_{f, A}^{\prime}(\mathrm{mg} / \mathrm{g})$ & $n$ & $R^{2}$ & $K_{f, D}^{\prime}(\mathrm{mg} / \mathrm{g})$ & $n$ & $R^{2}$ & \\
\hline \multicolumn{8}{|c|}{ Primary sludge } \\
\hline Raw & 2.595 & 0.997 & 0.994 & 2.824 & 1.015 & 0.993 & 1.02 \\
\hline $375^{\circ} \mathrm{C}$ & 0.663 & 0.874 & 0.992 & 1.219 & 0.831 & 0.988 & 0.95 \\
\hline $600^{\circ} \mathrm{C}$ & 0.128 & 0.837 & 0.962 & 0.092 & 0.497 & 0.797 & 0.59 \\
\hline \multicolumn{8}{|c|}{ Anaerobic sludge } \\
\hline Raw & 1.979 & 0.958 & 0.998 & 2.499 & 0.940 & 0.989 & 0.98 \\
\hline $375^{\circ} \mathrm{C}$ & 0.261 & 0.774 & 0.953 & 1.067 & 1.196 & 0.988 & 1.55 \\
\hline $600^{\circ} \mathrm{C}$ & 0.090 & 0.912 & 0.967 & - & - & - & - \\
\hline \multicolumn{8}{|c|}{ Anoxic sludge } \\
\hline Raw & 2.634 & 1.010 & 0.988 & 3.220 & 1.039 & 0.984 & 1.03 \\
\hline $375^{\circ} \mathrm{C}$ & 3.431 & 0.592 & 0.998 & 5.551 & 0.635 & 0.999 & 1.07 \\
\hline $600^{\circ} \mathrm{C}$ & 0.575 & 1.289 & 0.974 & 1.476 & 1.189 & 0.975 & 0.92 \\
\hline \multicolumn{8}{|c|}{ Aerobic sludge } \\
\hline Raw & 2.682 & 1.044 & 0.994 & 4.258 & 1.090 & 0.975 & 1.04 \\
\hline $375^{\circ} \mathrm{C}$ & 0.605 & 0.533 & 0.985 & 1.191 & 0.592 & 0.998 & 1.11 \\
\hline $600^{\circ} \mathrm{C}$ & 0.125 & 0.510 & 0.912 & 0.726 & 0.842 & 0.912 & 1.65 \\
\hline \multicolumn{8}{|l|}{ Sludge cake } \\
\hline Raw & 2.277 & 1.006 & 0.998 & 2.335 & 0.958 & 0.983 & 0.95 \\
\hline $375^{\circ} \mathrm{C}$ & 0.642 & 0.651 & 0.990 & 1.162 & 0.689 & 0.99 & 1.06 \\
\hline $600^{\circ} \mathrm{C}$ & 0.052 & 0.677 & 0.927 & - & - & - & - \\
\hline
\end{tabular}


Table 4 Organic matter normalized $\mathrm{K}_{\mathrm{f}}$ and Gibbs free energy change of $\mathrm{EE}_{2}$ adsorbing and desorbing from various sludge

\begin{tabular}{|c|c|c|c|c|c|}
\hline \multirow[t]{2}{*}{ Sludge type } & \multirow[t]{2}{*}{$f_{\mathrm{oc}}(\%)$} & \multicolumn{2}{|c|}{ Adsorption } & \multicolumn{2}{|c|}{ Desorption } \\
\hline & & $K_{\mathrm{OC}, A}$ & $\Delta G_{a}^{\circ}(\mathrm{kJ} / \mathrm{mol})$ & $K_{\mathrm{OC}, D}$ & $\Delta G_{d}^{\circ}(\mathrm{kJ} / \mathrm{mol})$ \\
\hline \multicolumn{6}{|c|}{ Primary sludge } \\
\hline Raw & 45.04 & 5.76 & -4.34 & 6.27 & -4.55 \\
\hline $375^{\circ} \mathrm{C}$ & 4.75 & 13.94 & -6.53 & 25.64 & -8.04 \\
\hline $600^{\circ} \mathrm{C}$ & 0.17 & 73.96 & -10.67 & 53.16 & -9.85 \\
\hline \multicolumn{6}{|c|}{ Anaerobic sludge } \\
\hline Raw & 42.46 & 4.66 & -3.82 & 5.89 & -4.39 \\
\hline $375^{\circ} \mathrm{C}$ & 3.36 & 7.76 & -5.08 & 31.74 & -8.57 \\
\hline $600^{\circ} \mathrm{C}$ & 0.30 & 29.60 & -8.40 & - & - \\
\hline \multicolumn{6}{|c|}{ Anoxic sludge } \\
\hline Raw & 46.05 & 5.72 & -4.32 & 6.99 & -4.82 \\
\hline $375^{\circ} \mathrm{C}$ & 11.63 & 29.51 & -8.39 & 47.75 & -9.58 \\
\hline $600^{\circ} \mathrm{C}$ & 0.20 & 283.64 & -14.00 & 728.10 & -16.34 \\
\hline \multicolumn{6}{|c|}{ Aerobic sludge } \\
\hline Raw & 46.85 & 5.72 & -4.32 & 9.09 & -5.47 \\
\hline $375^{\circ} \mathrm{C}$ & 4.40 & 13.75 & -6.50 & 27.06 & -8.18 \\
\hline $600^{\circ} \mathrm{C}$ & 0.33 & 37.71 & -9.00 & 219.01 & -13.36 \\
\hline \multicolumn{6}{|l|}{ Sludge cake } \\
\hline Raw & 44.01 & 5.17 & -4.07 & 5.31 & -4.14 \\
\hline $375^{\circ} \mathrm{C}$ & 6.57 & 9.77 & -5.65 & 17.68 & -7.12 \\
\hline $600^{\circ} \mathrm{C}$ & 0.20 & 25.33 & -8.01 & - & - \\
\hline
\end{tabular}

sludge were again fitted well by modified Freundlich model. For each sludge, $K_{f, A}^{\prime}$ value decreased with the organic carbon (OC) content, and the adsorption capacity of $600^{\circ} \mathrm{C}$ treated sludge was only $2.3-4.9 \%$ (21.8\% for anoxic sludge) of the raw sludge, which indicated that organic carbon of sludge was vital for $\mathrm{EE}_{2}$ adsorption. After treating at $375^{\circ} \mathrm{C}$, the sludge contained only the black carbon (BC), and $K_{f, A}^{\prime}$ value increased with the increase of the black carbon content of sludge $\left(K_{f, A}^{\prime}=0.3810 \mathrm{C}-1.222, R^{2}=0.922\right)$, which meant that $\mathrm{EE}_{2}$ adsorption capacity had a positive relationship with the black carbon content. Moreover, $\mathrm{EE}_{2}$ adsorption capacities of $375^{\circ} \mathrm{C}$-treated sludge were largely reduced: $K_{f, A}^{\prime}$ value ranged from 0.261 to $0.663 \mathrm{mg} / \mathrm{g}(3.431$ for anoxic sludge), which was only $13.2-28.2 \%$ of the raw sludge. The $f_{\mathrm{BC}} / f_{\mathrm{OC}}$ ratios were in the range of $0.08-0.25$, which indicated that most of the organic materials in the raw sludge were amorphous organic matter, whose adsorption capacity was lower than that of black carbon. The influence of organic carbon on the $K_{\mathrm{OC}, \mathrm{D}}$ and Gibbs free energy change of the desorption process are shown in Table $4 . K_{\mathrm{OC}, \mathrm{D}}$ was larger than the corresponding $K_{\mathrm{OC}, \mathrm{A}}$. For $375^{\circ} \mathrm{C}$-treated sludge (except for anoxic sludge), $K_{\mathrm{OC}, \mathrm{D}}$ values decreased with the increase of black carbon content of sludge $\left(K_{\mathrm{OC}, \mathrm{D}}^{\prime}=-4.3710 \mathrm{OC}+46.382, R^{2}=0.999\right)$, which meant that $\mathrm{EE}_{2}$ desorption capacity had a negative relationship with the black carbon content.
The $\Delta G^{\circ}$ of adsorption and desorption process are listed in Table 3 . The magnitude of $\Delta G^{\circ}$ is used to measure the extent of the reaction driving force. The greater the absolute magnitude of $\Delta G^{\circ}$ value, the greater is the extent of $\mathrm{EE}_{2}$ adsorption was (Krishna and Philip 2008). The small negative value of free energy change indicated that the adsorption process of $\mathrm{EE}_{2}$ on various sludges was self-motion and the $\mathrm{EE}_{2}$ molecule was inclined to transport from the solution to the sludge surface. It may also be inferred that adsorption is a physical process involving weak forces of attraction, such as van der Waals force, dipole attraction, etc. Moreover, the negative $\Delta G^{\circ}$ values represented that $\mathrm{EE}_{2}$ adsorption was exothermic and decreased with increase in temperature. The $\Delta G^{\circ}$ of desorption was similar to the adsorption process, which indicated that desorption was also conducted spontaneously.

\section{Effect of sludge concentration on $\mathrm{EE}_{2}$ adsorption}

Figure 2 shows that the adsorbed $\mathrm{EE}_{2}$ on various sludges decreases from $0.95-1.39 \mathrm{mg} / \mathrm{g}$ to $0.44-0.49 \mathrm{mg} / \mathrm{g}$ with increase in sludge concentration from 500 to $4,000 \mathrm{mg} / \mathrm{L}$. The reduction of adsorbed $\mathrm{EE}_{2}$ was above $53 \%$. The average $\mathrm{EE}_{2}$ adsorption amount $\left(Q_{\mathrm{EE} 2}\right)$ of the five different sludges had a linear relationship with $\operatorname{Ln}\left(C_{\text {sludge }}\right)$, as in the equation of $Q_{\mathrm{EE} 2}=-0.3499 \operatorname{Ln}\left(C_{\text {sludge }}\right)+3.3556, R^{2}=$ 0.9992. However, the $\mathrm{EE}_{2}$ removal efficiency increased 


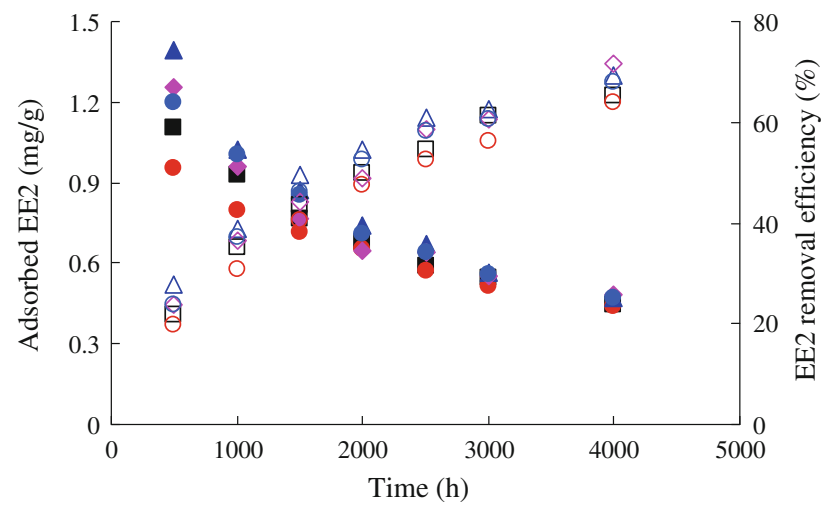

Fig. 2 Effect of sludge concentration on the $\mathrm{EE}_{2}$ adsorption amount and removal efficiency of various sludges (Initial $\mathrm{EE}_{2}$ concentration $2.78 \mathrm{mg} / \mathrm{L}$; temperature $25^{\circ} \mathrm{C}$; agitation $150 \mathrm{rpm}$; $\mathrm{pH} 6.9$; filled square, open square primary sludge; filled circle, open circle anaerobic sludge; filled triangle, open triangle anoxic sludge; filed diamond, open diamond aerobic sludge; filed circle, open circle sludge cake)

from $19.7-27.6$ to $64.0-71.7 \%$ for various sludges, and the effect of aerobic sludge was the best. The average $\mathrm{EE}_{2}$ removal rate $(\eta)$ also had a linear relationship with $\operatorname{Ln}\left(C_{\text {sludge }}\right)$, and the equation was: $\eta=21.407 \mathrm{Ln}\left(C_{\text {sludge }}\right)-$ $111.03, R^{2}=0.9955$. The relationships could be used to estimate the amounts of $\mathrm{EE}_{2}$ adsorbed on sludge and the removal efficiency from the aqueous phase at certain conditions in real wastewater treatment projects.

A similar phenomenon was observed in $\mathrm{Zn}$ (II) adsorption to Chinese loess, and the adsorption amount decreased from 69 to $18 \mathrm{mg} / \mathrm{g}$ with the increase in soil concentration from 2 to $10 \mathrm{~g} / \mathrm{L}$ (Tang et al. 2009). With increase in sludge concentration, the hydrolysis radius of sludge particles became less due to chemical interactions, such as flocculation and the overlap of the hydrolysis layers between colloid particles, which led to the reduction of effective adsorption sites for the same amount of sludge and decreased the unit adsorption capacity. However, the higher the sludge concentration, the more the absolute amount of effective adsorption sites was, and so the removal efficiency was still relatively much higher.

\section{Effect of $\mathrm{pH}$ and ion strength on $\mathrm{EE}_{2}$ adsorption}

Adsorption isotherms of $\mathrm{EE}_{2}$ on activated sludge at seven different $\mathrm{pH}$ values are shown in Fig. 3a. It showed that the $\mathrm{EE}_{2}$ adsorption on sludge was almost unchanged at $\mathrm{pH}$ value of 3-10.1 and was maintained in the range of $2.3-2.7 \mathrm{mg} / \mathrm{g}$. However, the adsorbed amount of $\mathrm{EE}_{2}$ decreased rapidly when the $\mathrm{pH}$ value increased over 10 . We could see that the adsorbed value was $0.318 \mathrm{mg} / \mathrm{g}$ at $\mathrm{pH} 12.0$, which was only $12.4 \%$ of that at $\mathrm{pH} 10.1$.

The surface charge of sludge is mainly negative in the $\mathrm{pH}$ range of 3.0-10.0 (Feng et al. 2010). When the $\mathrm{pH}$
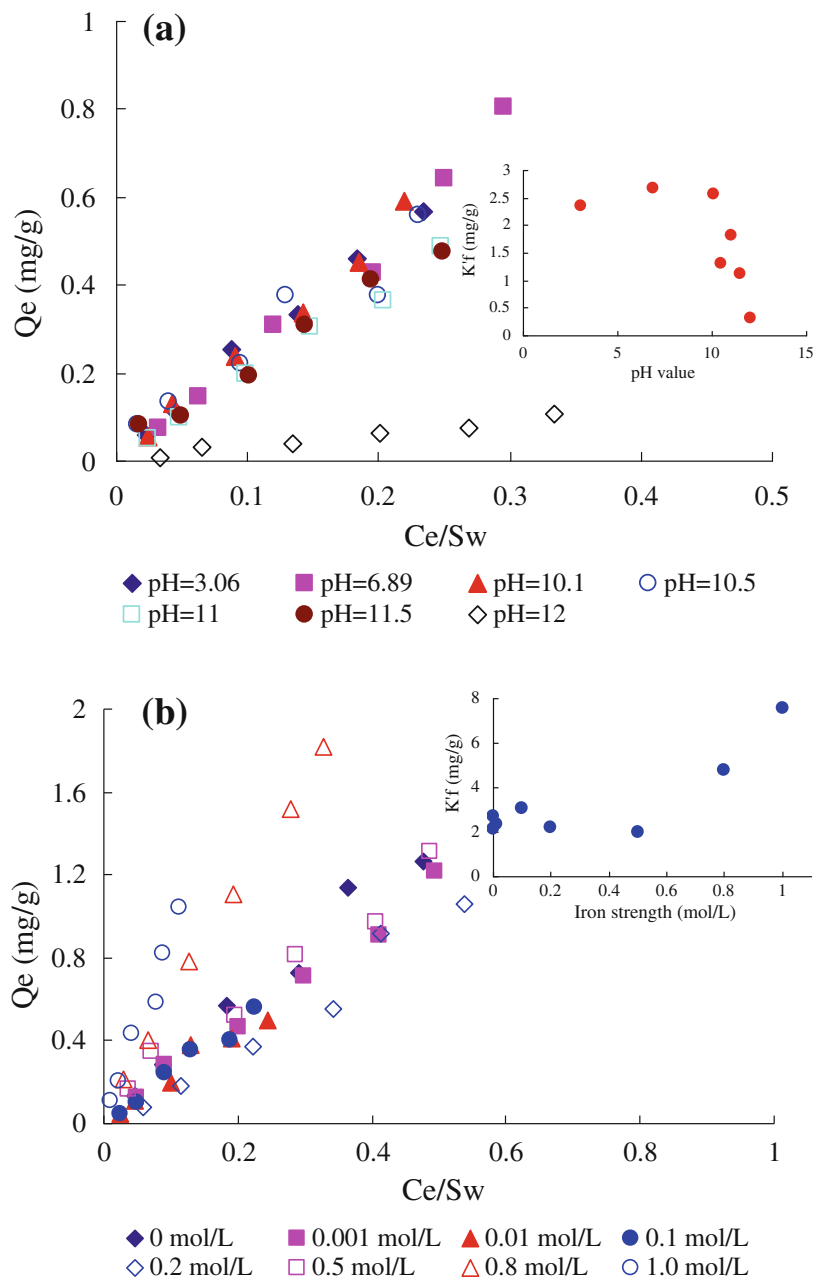

Fig. 3 Effect of pH value (a) and ion strength (b) on the equilibrium adsorption isotherm of $\mathrm{EE}_{2}$ on the aerobic sludge (initial $\mathrm{EE}_{2}$ concentration $1.72 \mathrm{mg} / \mathrm{L}$ (a) and $3.72 \mathrm{mg} / \mathrm{L}$ (b); temperature $25^{\circ} \mathrm{C}$; agitation $150 \mathrm{rpm}$; sludge concentration $1,000 \mathrm{mg} / \mathrm{L} ; \mathrm{pH}$ 6.9)

value was below $10, \mathrm{EE}_{2}$ mainly existed in the molecular form because $\mathrm{p} K_{\mathrm{a}}$ of $\mathrm{EE}_{2}$ molecule at $25^{\circ} \mathrm{C}$ was 10.5 and prone to adsorb on sludge by electrostatic interaction. The hydrogen binding between the hydroxyl group of $\mathrm{EE}_{2}$ and the functional groups on the sludge surface such as carboxylic group might play a major role in $\mathrm{EE}_{2}$ adsorption. With increase in the solution $\mathrm{pH}$ value (above 10), the sludge surface takes a more negative charge, and the concentration of the anionic form of $\mathrm{EE}_{2}$ increases accordingly and that of non-ionized $\mathrm{EE}_{2}$ will be less. Due to the electrostatic repulsion between anionic $\mathrm{EE}_{2}$ and negatively charged sludge surface, the anionic form of $\mathrm{EE}_{2}$ appeared to adsorb less than the non-ionized form (Gupta et al. 2006). Moreover, with increase in $\mathrm{pH}$ value, more $\mathrm{OH}^{-}$ions would exist in the solution and compete with the $\mathrm{EE}_{2}$ molecules for adsorption sites. The combination effects resulted in low $\mathrm{EE}_{2}$ adsorption at higher $\mathrm{pH}$ value. The effect of ion strength on $\mathrm{EE}_{2}$ adsorption capacity of 
activated sludge is shown in Fig. 3b. Two distinct stages of adsorption are exhibited with increase in $\mathrm{Ca}^{2+}$ concentration. When $\mathrm{Ca}^{2+}$ concentration was $<0.5 \mathrm{~mol} / \mathrm{L}$, it changed little and fluctuated in the range of $2.0-3.0 \mathrm{mg} / \mathrm{g}$, while with $\mathrm{Ca}^{2+}$ concentration $>0.5 \mathrm{~mol} / \mathrm{L}$, it increased rapidly and reached $7.6 \mathrm{mg} / \mathrm{g}$ at the $\mathrm{Ca}^{2+}$ concentration of $1.0 \mathrm{~mol} / \mathrm{L}$. This phenomenon might be attributed to several reasons such as screening the negative charge of sludge surface, formatting neutral ion pairs, decreasing $\mathrm{EE}_{2}$ solubility by the salting out effect and inhibiting $\mathrm{EE}_{2}$ molecular release (Sun et al. 2008). Moreover, the solution $\mathrm{pH}$ decreased with increase in $\mathrm{Ca}^{2+}$ concentration due to the exchange of $\mathrm{H}^{+}$by $\mathrm{Ca}^{2+}$ on the sludge surface, which also benefited the $\mathrm{EE}_{2}$ adsorption.

\section{Effect of solvents on $\mathrm{EE}_{2}$ desorption}

The hydrophilic methanol and acetonitrile were selected to investigate the influence of organic solvents on the desorption capacity of $\mathrm{EE}_{2}$ from sludge by varying the volume content of $0-50 \%$ in the eluent. As shown in Fig. 4, distilled water could desorb $41.2 \%$ of adsorbed $\mathrm{EE}_{2}$ from sludge, where the equilibrium adsorption capacity was $0.45 \mathrm{mg} / \mathrm{g}$. As expected, addition of organic solvents improved the desorption effect. In the case of methanol, the residual $\mathrm{EE}_{2}$ on the sludge decreased from 0.265 to $0.053 \mathrm{mg} / \mathrm{g}$ with increase of methanol content (0-50\%), while $\mathrm{EE}_{2}$ in aqueous phase increased from 0.371 to $0.794 \mathrm{mg} / \mathrm{L}$. The $50 \%$ methanol eluent desorbed $88.2 \%$ of adsorbed $\mathrm{EE}_{2}$, which was 2.14 times that with distilled water as eluent. For the acetonitrile case, the residual $\mathrm{EE}_{2}$ on sludge decreased from 0.265 to $0.012 \mathrm{mg} / \mathrm{g}$, and $\mathrm{EE}_{2}$ in aqueous phase increased from 0.371 to $0.875 \mathrm{mg} / \mathrm{L}$. The desorbed percentage was $97.2 \%$ and 2.36 times of that in distilled water. By comparison, when $\mathrm{EE}_{2}$ was evaluated on

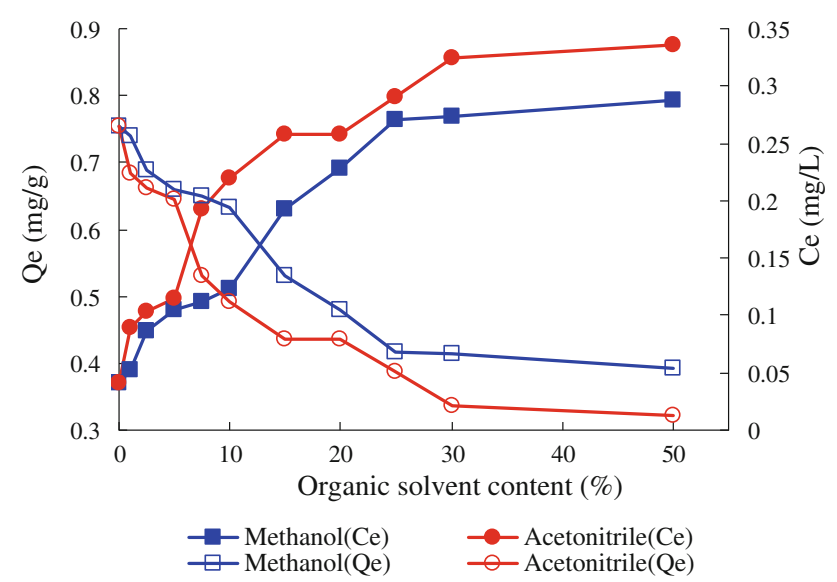

Fig. 4 Effect of organic solvent content on the desorption behavior of $\mathrm{EE}_{2}$ from the aerobic sludge (initial $\mathrm{EE}_{2}$ concentration $1.72 \mathrm{mg} / \mathrm{L}$; temperature $25^{\circ} \mathrm{C}$; agitation $150 \mathrm{rpm}$; sludge concentration $2,000 \mathrm{mg} /$ L; pH 6.9) sludge or sediment, the desorption degree of acetonitrile eluent was higher than that of methanol, which meant that acetonitrile was a better choice. Moreover, when the volume content of the two organic solvents was above $30 \%$, the adsorbed $\mathrm{EE}_{2}$ varied slightly and steadily on the whole.

$\mathrm{EE}_{2}$ adsorption, which was related to the $\mathrm{EE}_{2}$ aqueous concentration and the organic matter content of the sludge, depended on the $\mathrm{EE}_{2}$ solubility in the liquid. Previous studies had shown that the adsorption of hydrophobic organic compounds decreased with the solubility of the contaminant in the liquid in a log-linear fashion (Khodadoust et al. 1999). With the increase in the co-solvent content, the $\mathrm{EE}_{2}$ solubility increased and adsorption decreased, which benefited $\mathrm{EE}_{2}$ desorption. In addition, $\mathrm{EE}_{2}$ adsorption on sludge was determined by the hydrophobic interactions, where the hydrophobic surface of sorbent (sludge) was in contact with a hydrophobic sorbate $\left(\mathrm{EE}_{2}\right)$. With the increase of organic cosolvent content, the carbonaceous surface area of sludge decreased and the hydrophobic interactions diminished, which resulted in higher mobility of $\mathrm{EE}_{2}$ in the absence of hindrance by diffusion through the organic matter. Therefore, a higher fraction of co-solvent in the solution enhanced the desorption of $\mathrm{EE}_{2}$.

\section{Conclusion}

The adsorption/desorption characteristics of $\mathrm{EE}_{2}$ on various sludges were studied. The fast adsorption was found playing a main role in the adsorption process. The adsorption rate was in the order of $\mathrm{AS} \approx \mathrm{AnaS}>\mathrm{PS}>\mathrm{AnoS} \approx \mathrm{CS}$. Modified Freudlich model could describe the adsorption isotherms of $\mathrm{EE}_{2}$ on five sludges. The adsorption capacity ranged from 1.98 to $2.68 \mathrm{mg} / \mathrm{g}$ (based on dry sludge) and followed a linear relationship with the organic carbon content in the sludge. After heat treatment for removing the organic carbon from the sludge, the $K_{f}^{\prime}$ value reduced by more than $78 \%$, but organic carbon-normalized adsorption constant increased. Thermodynamic analysis indicated that $\mathrm{EE}_{2}$ adsorption/desorption was exothermic and happened spontaneously. The HI value was above 0.92 indicating that there was almost no hysteresis effect in desorption.

It was also found that the adsorption capacity of $\mathrm{EE}_{2}$ on sludge decreased under higher sludge concentration and higher $\mathrm{pH}$ value, and increased under higher ionic strength. The organic co-solvent improve the desorption effect, and the desorption degree of acetonitrile eluent was higher than that of methanol. These findings are important to assess the transport and fate of $\mathrm{EE}_{2}$ and other estrogens in sewage treatment plants.

Acknowledgments This study was supported by the National Major Science and Technology Projects for Water Pollution Control and Governance (2009ZX07207-008-5-2), the Key Science \& Technology 
Program of Heilongjiang Province (WB10A401) and State Key Laboratory of Urban Water Resource and Environment, Harbin Institute of Technology (2009TS04). The authors also acknowledge the support of National Creative Research Groups of China (50821002) and the National Science Fund for Distinguished Young Scholars (51125033).

\section{References}

Andersen HR, Hansen M, Kjolholt J, Stuer-Lauridsen F, Ternes T, Halling-Sorensen B (2005) Assessment of the importance of sorption for steroid estrogens removal during activated sludge treatment. Chemosphere 61(1):139-146

Cargouet M, Perdiz D, Mouatassim-Souali A, Tamisier-Karolak S, Levi Y (2004) Assessment of river contamination by estrogenic compounds in Paris area (France). Sci Total Environ 324(1-3):55-66

Carmo AM, Hundal LS, Thompson ML (2000) Sorption of hydrophobic organic compounds by soil materials: application of unit equivalent Freundlich coefficients. Environ Sci Tech 34(20):4363-4369

Chang H, Hu J, Shao B, Xu Y, Gao J, Dong M (2003) Determination of trace estrogens in surface water using SPE-LC-MS. Environ Chem 22:400-403

Cirja M, Zuehlke S, Ivashechkin P, Hollender J, Schaffer A, Corvini PFX (2007) Behavior of two differently radiolabelled 17 alphaethinylestradiols continuously applied to a laboratory-scale membrane bioreactor with adapted industrial activated sludge. Water Res 41(19):4403-4412

Clara M, Strenn B, Saracevic E, Kreuzinger N (2004) Adsorption of bisphenol-A, 17 beta-estradiole and 17 alpha-ethinylestradiole to sewage sludge. Chemosphere 56(9):843-851

Cui CW, Ji SL, Ren HY (2006) Determination of steroid estrogens in wastewater treatment plant of a contraceptives producing factory. Environ Monit Assess 121(1-3):409-419

Feng Y, Zhang Z, Gao P, Su H, Yu Y, Ren N (2010) Adsorption behavior of $\mathrm{EE}_{2}$ (17alpha-ethinylestradiol) onto the inactivated sewage sludge: kinetics, thermodynamics and influence factors. J Hazard Mater 175(1-3):970-976

Fent K, Escher C, Caminada D (2006) Estrogenic activity of pharmaceuticals and pharmaceutical mixtures in a yeast reporter gene system. Reprod Toxicol 22(2):175-185

Flores C, Morgante V, Gonzalez M, Navia R, Seeger M (2009) Adsorption studies of the herbicide simazine in agricultural soils of the Aconcagua valley, central Chile. Chemosphere 74(11): $1544-1549$

Gupta VK, Ali I, Suhas, Saini VK et al (2006) Adsorption of 2,4-D and carbofuran pesticides using fertilizer and steel industry wastes. J Colloid Interface Sci 299(2):556-563

Ifelebuegu MO (2011) The fate and behaviour of selected endocrine disrupting chemicals in full scale wastewater and sludge treatment unit processes. Int J Environ Sci Tech 8(2):245-254

Ifelebuegu AO, Theophilus SC, Bateman MJ (2010) Mechanistic evaluation of the sorption properties of endocrine disrupting chemicals in sewage sludge biomass. Int $\mathrm{J}$ Environ Sci Tech 7(4):617-622

Johnson AC, Williams RJ (2004) A model to estimate influent and effluent concentrations of estradiol, estrone, and ethinylestradiol at sewage treatment works. Environ Sci Technol 38(13):3649-3658

Kanda R, Churchley J (2008) Removal of endocrine disrupting compounds during conventional wastewater treatment. Environ Tech 29(3):315-323

Kannan N, Sundaram MM (2001) Kinetics and mechanism of removal of methylene blue by adsorption on various carbons-a comparative study. J Dye Pigmen 51(1):25-40
Khanal SK, Xie B, Thompson ML, Sung SW, Ong SK, Van Leeuwen J (2006) Fate, transport, and biodegradation of natural estrogens in the environment and engineered systems. Environ Sci Tech 40(21):6537-6546

Khodadoust AP, Suidan MT, Sorial GA, Dionysiou DD (1999) Desorption of pentachlorophenol from soils using mixed solvents. Environ Sci Tech 33(24):4483-4491

Krishna KR, Philip L (2008) Adsorption and desorption characteristics of lindane, carbofuran and methyl parathion on various Indian soils. J Hazard Mater 160(2-3):559-567

Kwak HI, Bae MO, Lee MH, Lee YS, Lee BJ, Kang KS, Chae CH, Sung HJ, Shin JS, Kim JH, Mar WC, Sheen YY, Cho MH (2001) Effects of nonylphenol, bisphenol A, and their mixture on the viviparous swordtail fish (Xiphophorus helleri). Environ Toxicol Chem 20(4):787-795

Leyva-Ramos R, Diaz-Flores PE, Leyva-Ramos J, Femat-Flores RA (2007) Kinetic modeling of pentachlorophenol adsorption from aqueous solution on activated carbon fibers. Carbon 45(11):2280-2289

Nash JP, Kime DE, Van der Ven LTM, Wester PW, Brion F, Maack G, Stahlschmidt-Allner P, Tyler CR (2004) Long-term exposure to environmental concentrations of the pharmaceutical ethynylestradiol causes reproductive failure in fish. Environ Health Perspect 112(17):1725-1733

Panter GH, Thompson RS, Beresford N, Sumpter JP (1999) Transformation of a non-oestrogenic steroid metabolite to an oestrogenically active substance by minimal bacterial activity. Chemosphere 38(15):3579-3596

Pignatello JJ, Xing BS (1996) Mechanisms of slow sorption of organic chemicals to natural particles. Environ Sci Tech 30(1):1-11

Pusino A, Pinna MV, Gessa C (2004) Azimsulfuron sorptiondesorption on soil. J Agric Food Chem 52(11):3462-3466

Ran Y, Sun K, Yang Y, Xing BS, Zeng E (2007) Strong sorption of phenanthrene by condensed organic matter in soils and sediments. Environ Sci Tech 41(11):3952-3958

Ren YX, Nakano K, Nomura M, Chiba N, Nishimura O (2007) A thermodynamic analysis on adsorption of estrogens in activated sludge process. Water Res 41(11):2341-2348

Soto AM, Justicia H, Wray JW, Sonnenschein C (1991) p-Nonylphenol: an estrogenic xenobiotic released from modified polystyrene. Environ Health Perspect 92:167-173

Sun ZH, Yu YJ, Mao L, Feng Z, Yu HX (2008) Sorption behavior of tetrabromobisphenol A in two soils with different characteristics. J Hazard Mater 160(2-3):456-461

Tang XW, Li ZZ, Chen YM (2009) Adsorption behavior of Zn(II) on calcinated Chinese loess. J Hazard Mater 161(2-3):824-834

Ternes TA, Stumpf M, Mueller J, Haberer K, Wilken RD, Servos M (1999) Behavior and occurrence of estrogens in municipal sewage treatment plants-I. Investigations in Germany, Canada and Brazil. Sci Total Environ 225(1-2):81-90

Thomas KV, Hurst MR, Matthiessen P, Waldock MJ (2001) Characterization of estrogenic compounds in water samples collected from United Kingdom estuaries. Environ Toxicol Chem 20(10):2165-2170

Tyler CR, Jobling S, Sumpter JP (1998) Endocrine disruption in wildlife: a critical review of the evidence. Crit Rev Toxicol 28(4):319-361

Xu K, Harper WF, Zhao DY (2008) 17 alpha-ethninylestradiol sorption to activated sludge biomass: thermodynamic properties and reaction mechanisms. Water Res 42(12):3146-3152

Zeng GM, Zhang C, Huang GH, Yu J, Wang Q, Li JB, Xi BD, Liu HL (2006) Adsorption behavior of bisphenol A on sediments in Xiangjiang River, Central-south China. Chemosphere 65(9):1490-1499

Zhang ZH, Feng YJ, Gao P, Wang C, Ren NQ (2011) Occurrence and removal efficiencies of eight EDCs and estrogenicity in a STP. J Environ Monitor 13(5):1366-1373 